\title{
SZIRMAI VIKTÓRIA (SZERK.): A VÁROSTÉRSÉGI VERSENYKÉPESSÉG TÁRSADALMI TÉNYEZÖI
}

(Dialóg Campus Kiadó, Budapest-Pécs, 2009. 319 o.)

\section{UZZOLI ANNAMÁRIA}

Hogyan lehetnek a magyar nagyvárostérségek versenyképesebbek? A mindenkor igen aktuális kérdés megválaszolására Szirmai Viktória professzor asszony és kutatócsoportja vállalkozott 2004-2007 között a Nemzeti Kutatási Fejlesztési Program támogatásával megszervezett projekt keretében. Több intézmény és különbözö tudományterületek jeles képviselői közremüködésével megvalósult empirikus kutatás kilenc magyarországi nagyváros (Budapest, Debrecen, Győr, Kecskemét, Miskolc, Nyíregyháza, Pécs, Szeged, Székesfehérvár) és térségeik térbeli társadalmi jellegzetességeinek, valamint az ezekkel kapcsolatos területi egyenlötlenségeknek és konfliktusoknak az értelmezését tủzte ki célul. Tulajdonképpen a kötet a legfontosabb kutatási eredmények bemutatása végett született meg, mégis az egyes vizsgálati témák elméleti hátterének nagyon komoly kidolgozása, a kutatási projekt lezárását követỏen a statisztikai adatok frissítése, a különféle elemzések módszertani sokszínủsége garantálja a könyv önálló életét és sikerét az elkövetkezendỏ években.

A gondosan szerkesztett, szép kivitelü, ábráiban precíz és egységes kötet egyben felvonultatja a kutatási témában releváns nemzetközi és hazai tudományos munkák tekintélyes részét is. Ez az elméleti megalapozás segít megérteni többek között az európai és hazai városfejlődést befolyásoló folyamatokat, a városkutatás módszertani problematikáját, az egyenlőtlenség fogalmát, a társadalmi konfliktusok értelmezésének lehetöségeit és azok kezelésének eszközeit, vagy éppen a versenyképesség mérésének kihívásait a területi folyamatok és a városok tekintetében. Azonban a hangsúly az empirikus eredmények elemzésén, s így a térbeli társadalmi egyenlőtlenségek újszerủ megközelítésén van. Egyrészt lenyủgöző a feldolgozott adatállomány (5248 kérdőív, 108 mélyinterjú, 1993-2007 közötti átfogó statisztikai adatbázis), másrészt pedig példamutató az alkalmazott kutatási módszerek alapos ismertetése (a szociológiai adatfelvételt például a TÁRKI ZRt. készítette).

A könyv szerkesztóje, valamint összesen tizenkét szerzője az új típusú társadalmi és területi egyenlőtlenségek magyarázatában mindvégig a komplex, interdiszciplináris értelmezés elkötelezett hívei. Különösen jónak találom, hogy a nagyvárosi terek jelenségeinek megvilágitásában prioritást kapott az a felfogás, hogy a városok ez idáig fóként gazdasági szempontú megközelítése mellett a társadalmi szempontokat is figyelembe kell venni. Sőt, a versenyképesség társadalmi tényezőinek sokdimenziós modellje kitért a városfejlődést befolyásoló ökológiai potenciál felmérésére is. 
A monográfia a kutatók részéről folyamatosan megfogalmazott, a tudományos probléma mélyebb megértését segitő, de egyértelmú kérdésekre keresi a válaszokat. Szerkezeti felépítése világos és áttekinthető, amivel a legjobban szolgálja a kutatás koncepciójának kidolgozását és az eredmények kiértékelését.

Az I. fejezet (Szirmai Viktória) a globalizáció nagyvárosokra kifejtett térbeli társadalmi, szerkezeti hatásait, az ezzel kapcsolatos nemzetközi trendeket mutatja be, természetesen a hazai városkutatási eredmények és irányzatok vizsgálata mellett. Legfontosabb megállapitása, hogy jelenleg az európai városkutatásokban paradigmaváltás játszódik le, ezért a hazai városkutatások modernizációjára is szükség van. Tulajdonképpen ehhez útmutató maga a könyv is, illetve az alapját megteremtő kutatási projekt, amely átfogó lehetőséget nyújtott a várostérségi problematika differenciált feltárására.

A II. fejezetben Baranyai Nóra és Váradi Zsuzsanna tömören, lényegre törően, de az igazán fontos részletek kiemelésével tárta fel a kutatás metodológiáját, a vizsgálatba bevont kilenc nagyvárostérség föbb társadalmi-gazdasági ismérveit. A térbeli társadalmi egyenlótlenségek területi dimenzió menti definiálása egységesen alkalmazott szempontrendszer alapján történt meg, amely így a munka folyamán hatékonnyá tette az összehasonlitás eszközeit. Az empirikus adatfelvétel és a statisztikai adatfeldolgozás a város - városkörnyék - várostérség területi relációk, a városon belül a belvárosi - átmeneti - külvárosi övezetek, a városkörnyéken a fejlett és a fejletlen háttértelepülések, valamint a budapesti várostérség és a vidéki várostérségek szerint zajlott le. Ezek a területi vizsgálati szintek késóbb az eredmények kiértékelésében jellemző térbeli konfliktusformák elkülönítését tették lehetővé.

A kötet gerincét a III. fejezet alkotja, amely tartalmilag és módszertanilag is igen változatos. Bevezetésképpen összegzi a legfontosabb térszerkezeti és városmodelleket (Molnár Balázs - Szirmai Viktória), majd a társadalmi szerkezeti egyenlötlenségek nagyvárostérségi sajátosságait különféle aspektusból elemzi. Ennek során többek között például a demográfiai helyzet (Baráth Gabriella - Váradi Zsuzsanna); a gazdasági környezet különbségei (Borbély Béláné - Balogh Eszter); az infrastrukturális, intézményellátottsági és foglalkoztatottsági egyenlőtlenségek (Molnár $B a-$ lázs - Szépvölgyi Ákos); valamint a természeti, táji és épített környezet átalakulásával kapcsolatos jellegzetességek (Schuchmann Péter - Károlyi János) kerülnek tárgyalásra. Kiváló, ahogy a fejezet tematikája a nagyvárostérségek társadalmi jellemzöit fokozatosan kiszélesedő térbeli kontextusban adja meg. Egészen merész, egyben szakmai kidolgozását tekintve rendkívül fegyelmezett a városok, városkörnyékek és várostérségek ellentmondásos folyamatainak magyarázatában egyrészt a klasszikus értelemben vett centrum-periféria modell használata, másrészt az újszerú megközelítés, azaz a konvergencia-divergencia kérdéskör, illetve a területi érdekellentétek alkalmazása. A társadalmi és területi konfliktusok e kettőss szerkezet mentén történö megjelenítése folyamatosan áthatja a mondanivalót, így a városok "fényes" és ,árnyékos" részeinek - például a belvárosok kapcsán - elemzése a gazdagság-szegénység, a csillogás-lepusztulás, a vitalitás-elöregedés, a dzsentrifikációmarginalizáció örök ellentétpárjaira hívja fel a figyelmet. 
A IV. fejezet a térbeli társadalmi egyenlőtlenségek és a társadalmi konfliktusok összefüggéseit vizsgálja. A társadalmi konfliktus problematika rövid elméleti háttere (Csizmadia Zoltán) bevezeti a nagyvárostérségi konfliktusérzékenység értékelését az elit (vezető) csoportokkal készített mélyinterjúk és a lakossági kérdőives felmérés kapcsán. A kutatócsoport tagjai ügyesen szintetizálták az ismereteket, igényesen transzformálták a kvalitatív módszerek eredményeit mérhető adatokká. A fejezet egyik fontos konklúziója, hogy a konfliktusfelfogásban az elit képviselöi számára a gazdasági és fejlesztési problémák hangsúlyosak, a lakosság számára pedig a társadalmi ellentétek a leglényegesebbek. Egyelöre sajátos a civil társadalmi szervezetek szerepe a helyi közösségi konfliktusok kezelésében, amely összefügg a hazai nonprofit szektor müködésének anomáliáival és hiányosságaival.

$\mathrm{Az} \mathrm{V}$. fejezetben teljesedik ki a kutatási eredmények interpretálása, a versenyképesség komplex értelmezése. Végső soron a versenyképes város élhető környezetet, illetve az életszínvonal-emelkedését, valamint a kedvezỏ életkörülmények együttesét jelenti. Azonban a gazdasági versenyképesség mást jelent a társadalmi versenyképességhez képest. Külön-külön és együttesen is különbözö rangsort eredményeznek a kilenc nagyvárostérségben. Söt, 1993 és 2005 között jelentös átrendeződések következtek be az egyes mintaterületeken (város-városkörnyék-várostérség szinteken), amelyek jelentős pozíció vesztéssel és/vagy nyeréssel párosultak. Szintén ötletes elgondolás volt a projekt résztvevői részéről, hogy a nagyvárosokat a lakossági adatfelvétel eredményeiből létrehozott társadalmi versenyképesség szerint is rangsorolták, így az „objektív" mutatók (statisztikai adatok) mellett a "szubjektív” tényezők is szerepet kaptak. Mindezek a vizsgálati módszerek az összesítésben lehetőséget adtak a városok, városkörnyékek és várostérségek tipizálására a komplex versenyképesség alapján. Ennek „elöremutató” eredményei mindenféleképpen új megközelítést és referenciát teremtenek a hazai városkutatásokban a jövőre nézve.

A VI. fejezetben ismételten remekül ötvöződik az elmélet és a gyakorlat a vizsgált témával kapcsolatban. Egyrészt olvashatunk a várostérségi konfliktusok kezelésének különféle közpolitikai modelljeiröl és technikáiról, illetve az ezekkel kapcsolatos nemzetközi és hazai tapasztalatokról (Hervainé Szabó Gyöngyvér). Másrészt betekintést kapunk a térségi versenyképesség növelését célzó tervezési eszközökbe, lehetőségekbe, gyakorlatba (Schuchmann Péter - Károlyi János - Burányi Endre). Fontos, hogy a fejezet megadja azokat a javaslatokat is, amelyek a tervezés térségi, stratégiai és integrált jellegének, azaz a várostérségi versenyképességnek az erősitéséhez járulhatnak hozzá.

A VII. fejezet nem csupán összegzése a leírtaknak és a vizsgálati eredményeknek, hanem igazán szuggesztív és informatív önálló tanulmány a nagyvárostérségek paradoxonjairól (Szirmai Viktória). A tapasztalatok és az eredmények alapján a kutatási projekt arra a megállapitásra jutott, hogy Magyarországon az utóbbi időben kibontakozott térbeli társadalmi folyamatok, vagyis a centrum és a városkörnyék differenciált, részben magas, részben alacsonyabb társadalmi tartalmai révén egy kettős struktúrájú térbeli társadalmi hierarchia jött létre. Az egyik térbeli társadalmi hierarchia a hagyományosnak nevezett magas státusú centrum és alacsony státusú 
periféria, míg a másik az alacsony státusú centrum és a magas státusú periféria modell szerveződését fejezi ki. A kutatás vezetője és a résztvevők javasolják e kettős struktúrájú centrum-periféria modell alkalmazását a nagyvárostérségek társadalmi és területi ellentmondásainak értelmezésében.

A kötet rendkívül aktuális, hisz a 2009-es világgazdasági válság nagy valószínűséggel új fejezetet nyit mind a városfejlödésben, mind pedig a versenyképesség definiálásában. Bár a kötet kéziratát 2007 októberében zárták le, mégis számos helyen olyan utalásokat, sőt kérdéseket tartalmaz, amelyek éppen a jelenlegi helyzetet vizionálták.

A könyv tartalmi és módszertani értékei a tudományos érdeklödés és a felsőoktatás számára is kitünő információszerzési forrás. Véleményem szerint releváns ismeretei és eredményei kapcsán joggal tarthat számot a „gyakorlat alkalmazói”, azaz a terület- és településfejlesztők, a várostervezök, a politikai döntéshozók, a civil szervezetek stb. szélesebb körének érdeklődésére is. 